\title{
Amerika Siyasi Tarihinde Başkan Martin Van Buren ve Döneminde İzlenilen İç-Dış Politikanın Analizi
}

\section{Analysis of the Domestic-Foreign Policy Followed by President Martin Van Buren's Period in American Political History}

\author{
İbrahim Kaya a , Engin Koç b,*
}

${ }^{a}$ MA. Bahçeșehir Üiversitesi, İstanbul/Türkiye.

ORCID: 0000-0002-9199-0227

b Dr. Öğr. Üyesi, Bursa Teknik Üniversitesi, İnsan ve Toplum Bilimleri Fakültesi, Uluslararası İlișkiler Bölümü, 16000, Bursa/Türkiye. ORCID: 0000-0003-3682-8718

\section{MAKALE BİLGISİ}

\section{Makale Geçmişi:}

Basvuru tarihi: 2 Kasım 2020

Düzeltme tarihi: 19 Ocak 2021

Kabul tarihi: 26 Ocak 2021

\section{Anahtar Kelimeler:}

Martin Van Buren

Amerikan siyasi Tarihi

Kölelik

Teksas'ın İlhakı

\section{ÖZ}

Martin Van Buren, bağımsız Amerika Birleşik Devletleri'nde doğan ilk ve aynı zamanda İngiliz kökenli olmayan ilk başkandır. Beyaz Saray'ın sekizinci başkanı olan Martin Van Buren bir hukukçu olmak ile birlikte onun siyaset ile ilgisi oldukça genç yaşlarda başlamıştır. Van Buren'in 1800 'de eyalet kongresinde delege olarak başlayan siyasi hayatı 1848 y1lında Free Soil olarak isimlendirilen, köleliğin yaygınlaşmasını önleme kampanyası ile son bulmuştur. Amerika siyasetinde valilik, vekillik, senatör, dış işleri bakanı, başkan yardımcısı ve nihayet başkanlık görevlerini icra eden Van Buren 1837 Paniği, Amerika'nın sınırlarının belirlenmesi, köleliğin yaygınlaştırılmasını engelleme meselesi, Teksas'ın Birleşik Devletlere kabulü meselesi, yerlilerin merkezi hükümete entegrasyonu gibi Amerika tarihi açısından önemli olaylar ile mücadele etmiştir. $\mathrm{Bu}$ çalışmada Martin Van Buren'in erken dönem siyasi hayatı, başkan seçilme süreci, başkanlık döneminde Amerika Birleşik Devletleri açısından hayati öneme sahip iç ve dış politik gelişmeler irdelenecektir. Çalışmanın bir bütün oluşturması ve kopuklukları ortadan kaldırmak adına, Van Buren'in başkanlık dönemine kadar Amerikan Siyasal Tarihi hakkında özet bilgi sunulacaktır.

\section{A B S T R A C T}

Martin Van Buren is the first president, who was born in the independent United States and first non-British origin among the presidents at the sametime. Martin Van Buren, the eighth president of the White House, became a lawyer and his interest in politics began very early age. The political life of Van Buren, which started as a delegate in the provincial congress in 1800, was ended Free Soil in 1848, and with the campaign to prevent the spread of slavery. Van Buren, who served as governor, deputy, senator, foreign minister, vice president and eventually president in American politics, he has struggled with important events is in terms of American history such as the panic of 1837, the determination of America's borders, the issue of preventing the spread of slavery, the annexation of Texas, the integration of the natives into the central government. In this study, will be examined Martin Van Buren's early political life, the process of being elected president, domestic and foreign political developments that are vital for the United States during his presidency. In order to create a whole in this study, brief information about American Political History will be presented until Van Buren's presidency.

\section{Giriş}

Modern anlamda ve uluslararası ilişkiler bağlamında yeryüzündeki birçok siyasi, iktisadi ve toplumsal gelişmelerin yoğun bir şekilde yaşandığg coğrafyanın Kita Avrupası olduğu düşünülmektedir. Avrupa'da yaşanan mezhep savaşları, yüzyıl savaşları, aydınlanma, Rönesans ve reform hareketleri özellikle özgür düşünce ve mutlakıyetçi

\footnotetext{
* Sorumlu yazar/Corresponding author.

e-posta: engin.koc@btu.edu.tr
} 
monarşilere karşı verilen hürriyet mücadelesinde önemli sosyal tecrübeler kazanılmıştır. Ayrıca Kita Avrupası ve Kitanın emperyalist ülkeleri olan İngiltere, Fransa, Hollanda, Portekiz ve İspanya arasında yaşanan rekabette modern ulus devletlerin kurulma sürecini hızlandırmıştır. $\mathrm{Bu}$ gibi gelişmeler aynı zamanda Amerika gibi politik, iktisadi ve sosyal anlamda kendine özgü iktisadi yapısıla bir kita devletinin bağımsızlığını ve bir süper güç olmasını dolaylı yollardan sağlamış ve ortaya önemli bir liberal güç çıkarmıştır.

İngiltere'nin Fransa ile uzun yıllar devam ettiği Amerika kıtasındaki hâkimiyet mücadelesinde 1756-1763 arasındaki Yedi Yıl Savaşını kazanması ile başlayan İngiltere'nin Amerika hâkimiyeti Asya ve Afrika'daki sömürgelerden oldukça farklı olarak Kuzey Amerika'yı liberal yöntemlerle sömürgeleştirmiştir. Kuzey Amerikalıların Kıta Avrupası'ndan dini kısıtlamalar ve yoksulluktan kaçtıkları düşünüldüğünde Kuzey Amerikalıların özgürlük ve refah temelli bir yaşam tarzı arayışında olduğu anlaşılmaktadır. Monarşinin gücünün ve aristokrasinin Amerika'dan uzak olması geniş kırsal alanların varlığı yeni Amerikalıların refahı açısından önem arz etmekteydi ve kıtada yaşayanlar arası dini hoşgörü baştan kabul edilmişti. Amerikalıların bölgede yaşayan Kızılderililere düşmanlığı ise beyazlar arasında ortak payda aidiyetine katkı sağlamıştır. İngiltere'nin Yedi Yıl Savaşlarının maliyetini Amerikan kolonilerinden karşılamak için vergi artırımına gitmesi İngiltere ve Kuzey Amerika'daki siyasetçilerin birbirine düşmesine neden olmuştur. Fransa'nın İngiltere'den intikam almak niyetiyle Kuzey Amerika kolonilerini desteklemesi ile 1774 yılında başlayan Amerikan bağımsızlık hareketi 1776 yılında bağımsızlığını ilan etti. İngiltere ise George Washington'un liderliğindeki ordu ile barış anlaşması imzalayarak 1782 yılında Amerika Birleşik Devletleri'ni tanıdı (Sander, 2009: 152-155). Amerika'nın tanınması Fransa açısından İngiltere'den intikam almayı ve İngiliz Krallığına karşı güç dengesi sağlamıştır.

Amerika Bağımsızlık Savaşı sonrası Fransa'nın ekonomisi hayli kötüye gitmiş, anayasal hak tartışmalarının artması ve yaşanan sosyal sorunlar Fransız Devrimini doğrudan tetiklemiştir. En önemlisi ise, Amerika'nın bağımsızlığı İngiltere ve Fransa'nın Kita Amerika'sındaki sömürgelerinde yaşayan halklara bağımsızlık ve özgürlük elde etme adına örnek teşkil etmiştir. Amerikan Bağımsızlık Savaşı sırasında bağımsızlık bildirisi hazırlanmış ve bu bildiride; tüm insanların eşit yaratıldığı, insanların doğuştan, devredilmez ve vazgeçilmez haklara sahip olduğunu vurgulayan maddelere yer verilmiştir (Özdal \& Karaca, 2015: 245-247). Fransızlar, Amerika'da yaşanan gelişmelerden oldukça etkilenmişler, bu da Paris merkezli daha devrimci fikirlerin ortaya çıkma sürecini hazırlamıştır.

Amerika'nın Avrupa'nın aydınlanma değerleri üzerine inşa edilmesi bu fikirlerin uygulanabilir olduğunun en büyük kanıtı olmuştur. Amerikan devriminden en çok etkilenen toplumsa şüphesiz ki Fransızlar olmuştur. Amerikalıların Fransızlara verdiği bağımsızlık ve hürriyet ilhamı Fransız Devrimini doğrudan tetiklemiştir. Ayrıca 1778 yılında Amerikan bağımsızlık bildirgesi basılarak Avrupa'ya dağıtılacaktır ki bu Avrupa'nın tamamında büyük tartışmalara neden olacaktır. Avrupa'da popüler düşünce olan insan hakları ve adalet gibi konular artık Avrupalı düşünürlerden ziyade Amerikalı entelektüellerden istifade edilme sürecine girmiştir. Amerikan yasaları Jean Jacques Rousseau'nun toplumsal sözleşmesinden uyarlanarak yasama, yürütme ve yargının tam anlamı ile birbirinden ayrıldığ1 felsefesi üzerine kurulmuştur (Sander, 2009: 157). $\mathrm{Bu}$ gelişmeler Avrupalı toplumların ütopya sandıkları düşüncelerin evrende karşılığı olduğu algısına ulaşmasına ve vatandaş hak ve hürriyetlerinin tanındığı, insanlara seçme ve seçilme hakkının mutlak surette sağlandığı fikir akımlarının güçlenmesini sağlayacaktır.

Birleşik Devletlerin İngiltere ile 1783 yılında barış anlaşması imzaladığında sınırları bugünkü sınırlarından oldukça farklı ve yüzölçümü oldukça küçüktü. Kuzey ve deniz kıyılarında toplanan nüfus, bağımsızlık sonrası Avrupa'dan gelen göçler ile ülkenin iç kesimlerine doğru nüfus artışı yaşanmıştır. İlk başta 13 eyalete sahip olan Amerika Birleşik Devletleri, 1791 yllında Kentucky, 1796'da Tennessee, 1803'te Ohio birliğe dahil edilmiştir. 1803 yılında Louisiana'yı Fransa'dan 15 milyon dolar karşılığında satın almıştır (Armaoğlu, 2014: 692-694). Birleşik Devletler, Almanya Federal Cumhuriyeti'nde olduğu gibi bir bütünden bölümleme değil tam aksine AB'de olduğu gibi devletlerden birleştirmedir. Bundan dolayı birliğe yeni katılan birimlerin öncesinde bir devlet oluşumu tamamlanır ve ardından Birleşik Devletler dediğimiz üst idari birime entegre edilir. Aksi durumda birliğe yeni katılan topraklar birliği oluşturan 13 devletten hangisinin toprağı olacağı sorunsalı çözülemez.

Amerika'nın giderek büyük bir coğrafyaya yayılması, sistematikleştirilmeye çalışılan politik yapısı ve mutlak özgürlükler ülkesi olmasına yönelik yapılan propagandalar, birçok Avrupalının Amerika kıtasında yaşamlarına devam etme kararını almalarında oldukça etkili olmuştur.

1823 Monreo Doktrini, Başkan Monreo'nun Kıta Avrupa'sındaki sistemin Amerika kıtasından uzak tutulması, Avrupa'nın sonu gelmez siyasi ve toplumsal sorunlarından uzak kalınmasını hedeflemiştir. Monreo Doktrini ile Avrupa'nın sorunlarından uzak duran Kuzey Amerika, enerjisini daha fazla Latin Amerika'ya kanalize etmiştir (Koç, 2017: 25). Bununla birlikte stratejik açıdan bakıldığında bu dönemde meşru ülke sınırlarını ve etkin olacağı nüfuz alanını tam belirlememiş ve ülke içi sorunlarda tatminkâr sonuçlara tam ulaşamamış olan Amerika'nın kendi içine kapanması oldukça mantıklı bir dış politika yönelimi olmaktadır. Amerika'nın coğrafi anlamda devasa bir boyuta sahip olması, hiç el değmemiş tarım ve madencilik kaynaklarına sahip olması ve Avrupa'dan refah ve özgür yaşamak için gelen nitelikli insan gücüne sahip olduğu düşünüldüğünde bu potansiyelin Amerikan devletinin gelişmesi ve kalkınmasına pozitif etkisi içe kapanmak değil de büyüme olarak da okunması gerekmektedir.

Amerika'da yukarıdaki satırlarda izah edilmeye çalışılan gelişmelerin yaşandığı bir dönemde Martin Van Buren'in Amerika siyasi hayatında ortaya çıkması bu süreç sonrasında yaşanacak olan gelişmelerin yönünün tayin edilmesinde oldukça belirleyici olacaktır.

\section{Martin Van Buren'in Siyasi Hayatından Kesitler}

Martin Van Buren Amerikan kolonilerin Britanya'dan bağımsızlıklarını almasından altı yıl sonra 5 Aralık 1782'de taverna sahibi çiftçi bir babanın oğlu olarak New York, Kinderhook'ta dünyaya geldi (History, 2009). Annesi Maria 
ve babası Abraham Hollanda'dan gelen göçmenlerdi. Maria Abraham ile evlenmeden önce üç çocuklu dul bir kadındır. Van Buren ailesi çok kolay olmayan yaşam koşullarında altı çocuklarıyla beraber yaşıyorlardı. Martin ailenin dördüncü çocuğuydu. Van Buren ailesi altı tane köle sahibiydi ve bu yaşadıkları zaman ve şartlarda anormal bir şey değildi. Köle sahibi olmak zenginlik alameti değildi, zaten Van Buren ailesi için zengin denilemezdi. Albany, Kinderhook birbirine yakın yerleşimlerdir, Albany'den gelen siyasetçiler ve hükümet görevlileri babasının tavernasında kalır ve orada toplantılar yaparlardı. Bu taverna aynı zamanda o bölgenin seçim çalışmaları içinde uzun yıllar bir merkez olarak kullanıldı. Babası gelirini artırmak adına şehirde bir memurluk görevi üstlenmişti. Tavernaya sik uğrayan bürokratlardan Alexsender Hamilton ve Aoran Burr genç Martin'in siyasi yeteneğini keşfetti (Silbey, 2020).

Martin, ailesinin onun çalışmasına ve yardımına ihtiyacı olduğu için Kinderhook'un tek sınıflı okulunda eğitimine on dört yaşına kadar devam etti. O günlerde çok üst perde sayılmayan koleje gitmedi. Babası siyasetçilerin yardımıyla genç Martin'i bir hukuk bürosuna çalışması için yerleştirdi. Martin temizlik ve günlük işler yaptığ boyunca geceleri hukuk çalıştı. Bir yıllığına New York'a taşındı. O yıllarda New York nüfusu 60.000 kişiydi. 1803 'te devlet barosuna kabul edildi. Van Buren erkek kardeşi James Van Allen ile ortak kendi hukuk bürosunu açtı. Genellikle mülk davalarına bakıyor ve topraklı seçkinlerin yerine kiracı halkın ve küçük toprak sahiplerinin yanında tavır alıyordu. $\mathrm{Bu}$ işten oldukça para ve itibar kazandı (Silbey, 2020).

Van Buren stajyer avukat olduğu dönemlerde, Francis Sylester'in yanında çalışmakta iken profesyonel anlamda siyaseti tanımaya başlamıştı. Federalist Parti'de politika ile aktif bir şekilde ilgilenen Sylester, güçlü federal hükümet ve zenginliğe destek çıkan hukuk kanunlarını desteklemekteydi. Van Buren'i federalistlere çekmeye çalışan Sylester, Van Buren'in koyu cumhuriyetçi fikirlere sahip olması nedeni ile çok başarılı olduğu söylenemez. Van Buren'in küçük çiftçi ve toprak sahiplerine olan ilgisi ve siyasi bakışı onun aktif politikaya daha hızlı girmesini sağlamıștır (Welcbacher, 2001: 10-11).

Hızlı bir şekilde New York siyasetinde yer edinen Van Buren. Önceleri Federalist Parti'de sonradan ise DemokratCumhuriyetçi partiye yöneldi. Parti başkanı DeWitt Clinton 1808 y1lında Van Buren'i devlet memurluğuyla (Columbia County vekilliği1808-1812) ödüllendirdi. Bir süre sonra parti içinde bölünmeler ve tartışmalar yaşandı. Van Buren bu dönemde, Buctails (şapkalarına bir geyik türünün kuyruklarından bir parça tüy iliştirdikleri için böyle anıldılar) diye anılan parti içi muhalif harekete liderlik yaptı (Silbey, 2020).

Van Buren 1808 y1lında Hannah Hoes ile evlenerek Houdson'a yerleşti. Mutlu bir evlilik ve aile yaşamına sahip olan Van Buren'in 1817'de beşinci oğlu doğduktan sonra Hannah yakalanmış olduğu ölümcül tüberküloz hastalığına yenik düşerek 1819 yılında hayata gözlerini yumdu. Martin Van Buren eşi Hannah öldükten sonra, oldukça çok evlilik teklifi alması ve duygusal yakınlık görmesine rağmen tekrar evlenmemeyi tercih etmiştir (US Senate, 2018). Bu süreç sonrasında yerel ve ulusal siyasete daha çok yönelmeye başlayan Van Buren, çok kısa bir zamanda siyasi basamakları oldukça hızlı bir şekilde çıkmıştır.
New York başsavcılığını yapan Van Buren ve muhalefeti oluşturan "Bucktails" isimli grup ile New York Belediye başkanı olan DeWitt Clinton'un cumhuriyetçilere karşı sadakatli olmadığını biliyorlardı, aynı zamanda belediye başkanının borçlulara hapis cezası verme cezasını tasvip etmiyorlardı 1817 yılında tekrar belediye başkanı seçilmesine rağmen 1819 yılında Van Buren New York eyalet meclisine seçilmiş Clinton ise valiliğe getirilmiştir ve 1820 yılında tekrar belediye başkanı seçilmiştir. Van Buren cumhuriyetçileri daha güçlü kılmak için birçok Bucktails'i kalifiyeli olmamasına rağmen iş sahibi yapmıştır. Amerika tarihinde oluşturulan ilk mekanizma olan bu muhalefeti birleștirme ve güçlendirme projesi aynı zamanda "spoils system" yani kayırma sistemi olarak bilinmekte ve The Albany Regency olarak uzun yıllar varlığını sürdürmüştür (Welcbacher, 2001: 13-14).

Martin Van Buren New York eyalet senatosunda 1812-1815 arası görev yaptı. 1812 savaşında savaş taraftarıydı. Federalistlerin savaş karşıtı olmalarını eleştirdi. Devletin savunma sistemini kolaylaştırmak ve güçlendirmek için yasa çıkarılmasında gayret gösterdi. 1815'te New York Başsavcısı oldu ve Albany'e taşındı. 1819 yılına kadar bu görevde kaldı ve 1820'ye kadar New York Eyalet Senatosu'nda görev yapmaya devam etti. Büyüyen hukuk bürosunu ortağı Benjamin F. Butler'a devretti. 1821 ve 1822 yıllarında Van Buren'in etkin olduğu Buctails gurubunun etkisiyle New York anayasasında köklü revizyonlar yapıldı. Oy kullanma hakkı genişletilerek genele yayıldı ve aristokrasinin etkisi kırıldı. De Witt Clinton'un Cumhuriyetçi Parti üzerindeki etkisini kıracak reformlarda yaptı. 1821 yılında Amerika Birleşik Devletleri Senatosu'na seçildi. Kurucusu olduğu sözünün geçtiği siyasi etkisi yüksek, partide kontrol kudreti olan Albany Regency siyasal örgütü Van Buren'in New York'taki gözü, kulağı ve eli olacaktır (US Senate, 2018).

1821-1828 yılları arasında Amerika Birleşik Devletleri Senatosu'na seçilen Van Buren 1829 yılında New York valisi olmuştur. Başkan Andrew Jackson'un teklifini kabul ederek 28 Mart 1829'da Amerika Birleșik Devletleri Dıșişleri Bakanı olarak atanmış, bu görevi 1831 Martına kadar sürdürmüştür. Dişişleri ile ilgili meselelere dikkatli bir yaklaşımı olması onun en önemli özelliği olmuştur. 18331837 yıllarında başkan yardımcılığı yapan Van Buren 1836 başkanlık seçimlerini kazanarak Amerika Birleşik Devletleri 8. Başkanı olmuştur (Department of State, 2018). Van Buren, kendisinden önceki başkanlardan farklı olarak İngiliz soyundan gelmeyen ilk Amerikan başkanıdır. Van Buren Hollanda kökenlidir. Aynı zamanda bağımsız Amerika Birleşik Devletleri'nde doğan ilk başkan olarak da tarihe geçmiştir ki kendisinden önceki bütün başkanlar İngiliz kolonilerinde doğmuştur (Welcbacher, 2001: 8).

Van Buren, giyimine özen gösteren, $1,68 \mathrm{~cm}$ boyunda ve hazır cevap bir siyasetçiydi. Sinsi politik manevralarından ötürü 'küçük sihirbaz' ve 'Kinderhook tilkisi' diye lakap takılan Van Buren kimileri içinde de kızıla çalan saçlarından ötürü 'kızıl tilki' olarak anılacak kadar siyasette ses getirmiş bir politikacıydı (Library of Congress, 2011). Van Buren 24 Temmuz 1862 yılında Kinderhook'da (Lindenwald) hayata gözlerini yumdu. Ömrünün son günlerinde Güney eyaletlerinin birlikten ayrıldığına ve ülkesinin iç savaşına şahit oldu. Fikren bölünmüş bir ülkeyi, müthiş çabalarla bir arada tutmaya katkısı olan bu adam için bu durum devasa bir 
hayal kırıklığıydı. Ölümünden önce Lincoln’un isyancı güçleri bastırmak için seferberlik çağrısına ve Lincoln yönetimine destek verdi. Lincoln onun ölümünden sonra, ondan ve arkadaşlarından övgüyle 'vatansever' diye bahsetti (Cole, 1984: 317-321).

Van Buren, Kinderhook'a iki kilometre kadar yakında Lindenwald diye anılan evinde 1841 'den ölüm tarihi olan 1862 yılına kadar yaşadı. İç savaştan sonra aile dişına satılan evini 1976 yılında National Park Service satın alarak bugün 'Martin Van Buren Ulusal Tarihi Sit Alanı' alanı olarak National Park Service içinde müze olarak hizmete sunmuştur (Richards, Miller, \& Gilg, 2006). Birçok Amerikalı diplomat ve tarihçi de dâhil olmak üzere birçok kişi Van Buren'i Amerika'nın gizemli ve oldukça etkisiz bir politik figür olarak kabul edip, Van Buran'in Amerika Birleşik Devletlerinekazandırdıklarını görmezden gelinmektedir. Van Buren'in ismi büyük başkanların listesinde hiçbir zaman görülmemiştir fakat bununla birlikte Amerika tarihindeki önemli başkanlardan biri olarak Amerikan ulusunun politik ve ekonomik kurumlarına büyük izler bırakmış bir lider olduğunu söyleyebiliriz (Rayback, 1983: 121). Çalışmanın ilerleyen sayfalarında Van Buren'in siyasi hayatı yanında başkanlığı döneminde Amerika Birleşik Devletleri'nde önemli iç ve diş politik gelişmelerden bahsedilerek Van Buren'in bu politikalara katkısı ve izlemiş olduğu stratejiler irdelenecektir

\section{Amerika'nın Genel Politik durumu ve Martin Van Buren'in Başkanlığa Giden Yolu}

Başkan Andrew Jackson döneminde Amerika'da demokrasi hareketleri oldukça genişlemiş ve toplumun alt kitlelerine yayılma süreci hızlanmıştır. 1830'lu yıllardan itibaren Güney Carolina hariç tüm eyaletlerde yetişkin erkeklere oy hakk1 verildi. 1824'te başkanlık seçiminde kullanılan oy $356.000,1836$ 'da $1.500 .000,1840$ 'ta ise bu rakam 2.400 .000 idi. Her ne kadar bu oyların artışında göçmenler faktörü olsa da çoğu oy hakkının genele yayılması ve halkta siyasete karşı ilginin artması daha çok etkili olmuştur (Nevis \& Commager, 2014: 212). Halkın siyasete karş1 ilgisinin artması ile birlikte Amerikan siyasi sisteminde etkili aktörler olan ve kitleler üzerinde dolaylı etkilere sahip olan lobi grupları da politik faaliyetlerini yoğunlaştırmışlardır.

Avrupa kıtasından uzak olan bu genç devlette her ne kadar demokrasi ve hürriyet atağa geçmiş ise de genelde Amerikan gazetelerinin büyük bölümü ticari ilanlar, çok küçük bir bölümü siyasi haberler ve sıradan haberlere ayrılırdı. Ancak bazen çok küçük bir köşede fikri ve siyasi tartışmaların olduğu kısa yazılara da rastlanırdı (Tocqueville, 1962: 43). Genç Amerika Birleşik Devletleri'nde birçok konuda demokrasi atakları yaşanıyordu. Herkesin kolaylıkla alabileceği düşük fiyatlı gazeteler çıkıyordu. 1833'te Benjamin Day 'New York' gazetesini çıkardı. 1835'te James Gordon Benett 'New York Herald' adlı gazeteyi çıkardı. İlk defa halk magazin dergisi 'Godey's Lady's Book' 1830'da Philadelphia'da çıkarılmaya başlandı. Geniş bir okur kitlesi olan ilk aylık edebi dergi 'Knickerbocker' 1833 yılında yayımlanmaya başladı. Eğitim alanında hiçbir dini kurumla ilişiği olmayan masrafları için bağış toplama yetkisi olan okulların hayata geçirilmesi için büyük çaba harcandı (Nevis \& Commager, 2014: 213). Zaten süregelen süreç zarfinda yavaş yavaş gelişmekte olan Amerikan demokrasisi peşinden, insan hakları, işçi hakları, kadın hakları ve kölelik karşıtlığı gibi yeni hak ve hürriyet hareketlerini kartopu misali hızla büyüttü.

Başkan Van Buren selefi olan Andrew Jackson ile sürdürdüğü güçlü ilişkiler kendisini Amerika Birleşik Devleti ve kongresi için hayati bir pozisyona taşımasını sağlamıştır. Ekonomik krizlere karşı mücadele ve dış politika ile ilgili konularda her zaman Van Buren'in fikri Başkan Andrew Jackson için önemli olmuştur. Özellikle 1832'de Beyaz Saray'daki bazı bürokratların Jackson'un Van Buren'i Amerika'nın İngiltere elçisi olarak ataması durumunda Amerikan Senatosunun bu kararı reddedeceği yaygarasına karşılık senatörlere uyarılarda bulunarak Van Buren'i İngiltere'ye elçi olarak göndermesi ve başkan yardımcılığı görevine getirmesi Van Buren'in Andrew Jackson için önemini göstermektedir (Jarvis, 1964: 21).

Van Buren, dışişleri bakanı görevini icra ederken Başkan Andrew Jackson'a 1830 Kızılderili Tehcir Yasası hakkında destek vermesi, İngiltere ve Fransa ile ticari anlaşmalar yapması, Osmanlı Devleti'nden Karadeniz'de serbest ticaret izni alması gibi önemli başarılara imza atmıştır. Bu başarılar Van Buren'in siyasette daha dikkat çekmesini sağlamıştır (Department of State, 2018). Van Buren, selefi Andrew Jackson ve yakın parti arkadaşlarının da desteği ile Amerikan başkanlık seçimlerine adaylığını koyma kararı almıştır.

1836 seçimi Amerika Birleşik Devletleri tarihi açısından da önemli bir seçim olmakla birlikte birkaç nedenden dolayı zihinlerde yer edinmiştir. Bunlar; 1888 yllına kadar hiçbir başkan yardımcısı Van Buren gibi başkanlık makamına seçimle ulaşmamıștır. Genellikle başkanın ya istifası ya da ölümü ile boşalan başkanlık makamı yardımcısının yasa gereği geçmesiyle doldurulmuştur. 1836 seçimi aynı zamanda büyük bir parti olan Whigs partisi farklı bölgelere dört farklı aday koyarak Van Buren'in düşük oy (kazanması için oyların yarısını geçmesi gerekir. Aksi durumda başkanı adaylar arasından Temsilciler Meclisi belirler.) alarak yenilmesini sağlayıp, kazanan Whigs adaylarından biri Temsilciler Meclisi tarafindan başkan olarak karar alınabilirdi. Fakat Demokrat bir aday olan Van Buren tüm bunlara rağmen 170 oy alırken dört rakibi toplam 124 oyda kalınca seçimi kazanarak başkan oldu. Ayrıca bu seçim başkan yardımcısının senato tarafından seçildiği bu tarihe kadarki ilk seçimdir (270towin, 2018).

Başkanlığı döneminde '1837 ekonomik buhranı', 1838'de 'Gözyaşı Yolu' diye adlandırılan ve binlerce insanın hayatına mal olan elim hadise vuku bulmuştur. 1839' da 'Amistad Davası' diye anılan İspanya İmparotorluğu ve Güney eyaletlerinin kuvvetli baskı yaptıkları köle davası (Amistad Davası) gibi Ameirka siyasi tarihi açısından oldukça önemli sonuçları olan olayları yönetebilmiş bir siyasi lider olarak Amerikan tarihine geçmiştir.

\section{Martin Van Buren ve Amerikan İç Politikası}

Van Buren, 1828 yılında Florida'nın birliğe katılımı için senatoya bir tasarı göndermiş fakat Florida'da köleliğin yasal olması nedeni ile bu tasarı tepki çekmiştir. Fakat Van Buren, köle sahiplerinin hukuki yapılanmasında negatif bir değişiklik olmayacağını fakat bu süreçten sonra köle ticareti yapılamayacağı hususunda diğer senatörleri ikna etmesi en 
önemli iç politik siyasi zaferlerinden biri olmuş ve bu onun 1828 y1lında New York valisi olmasında önemli rol oynamıştır (Welcbacher, 2001: 18). Van Buren, başkan olmadan Amerikan toplumu tarafından oldukça kabul edilen ve aşırı uçlar arasında mutedil bir yol izleyen siyasetçi olarak bilindiği için 1837 yılında başkanlık görevine başladığında Amerikan halkının iç politika da Van Buren'den oldukça yüksek beklentileri bulunduğu sonucuna varılabilir.

Van Buren, geleneksel Jeffersoncu devlet (eyalet-state) hakları kavramını kullanmaya devam etmiştir. Yani; federal (merkezi; çatı idare) hükümetin gücünü kısıtlayarak devletin ekonomide daha aktif bir yeri olmasını teşvik ederek modern siyasi partiler için ideal bir politik çerçeve vaat etti. Böylelikle, Erie Kanalı gibi ekonomiyi canlandırıcı projelerin katılımcı devletlerin (eyalaet-state) iç girişimleriyle geliştirilmesini tercih ederken devletlerin bu tür projeleri inşa etmeleri ve finanse etmeleri konusunda 1srarını devam ettirmiştir (Curtis, 2002: 126). Amerika Birleşik Devletleri'nde eyaletler tam olarak Türkçede anladığımız anlamı karşılamaz. Daha çok devlet tarzı bir yapıdır. En iyi karşılığı İngilizcedeki 'state' kelimesidir. Jefferson ve Van Buren gibi siyasetçiler tüm egemenliğin federal hükümette olmasına karşı çıkmış ve birliği oluşturan devletlerin karar almada federal hükümetten daha etkin konumda olmasını savunmuşlardır.

Martin Van Buren, siyasi ve sosyal hayatta partilerin zaruri varlığına ve faydalı olduklarına bütün gücü ile inanmış bir liderdir. Van Buren ayrica partilerin siyasi sistem içinde yararlı bir işlevi yerine getirdiğini ileri süren ayrıntılı bir argüman inşa eden ilk önde gelen devlet adamıdı. Bunu "siyasi partiler olmaksızın bir ülke tam özgür olamaz" sözü ile doğrulamaya çalışmıştır. Ayrıca iki partili seçime gidilmeyi ülkenin menfaati ve halkın dikkatini çekme adına oldukça olumlu karşılamıştır. Bugün ki Amerikan siyasi sistemindeki iki partili seçim sisteminin mimarisinde önemli katkılar sunmaktadır (Mintz M., 1949: 430). ABD'de sürekli olarak iki partinin varlığının hissedilmesi herhangi bir kural veya kanuna dayanmaz, seçim sisteminden kaynaklı fiili olarak böyle bir sonuç ortaya çıkmıştır. Ayrıca, iki partiden daha fazla partileri her seçimde görmek mümkündür fakat kamuoyu oluşturamayıp çok az oy potansiyeli oldukları için önemsizdirler. İlaveten, birçok seçimlerde bağımsız adaylarda bulunmaktadır.

\subsection{Finansal Krizi}

"1837 Paniğì” olarakifade edilen Amerikan finans krizi, halkın devlet ve bankalara güven eksikliği ile sonuçlanan istikrarsız bir döviz birimi ve finansal sistemi içeren bir olayd1. Bu kriz Başkan Andrew Jackson'un devlete ait fonları 1833'te Amerika Birleşik Devletler Bankası'ndan (Merkez Bankası) alıp, eyalet bankalarına devredildiğinde "bağımsız bir hazine sistemi" ortaya çıkmasını sağlamıştır. New Orleans'ta pamuk firmalarının iflası, şişirilmiş arazi fiyatlandırmaları ve spekülasyonlar krize katkı sağlamıştır. New York Bankası başta olmak üzere ABD'de 800 banka altın ödemelerini askıya aldı ve yılsonuna kadar 618 banka iflas etti. Birçok insan işsiz kaldı hatta temel gıda elde etme sıkıntısı yaşadı. Van Buren 1840 yılında bütün bankalardan bağımsız hazine kursa ve krizi kontrol altına almaya çalışsa da başkanlık döneminde bu krizi sonlandıramamıştır (Healy, 1964: 23; Armstrong Economics, 2018).
Başkan Van Buren, devlet bankalarına emanet edilen hükümet fonlarının güvenliği konusunda endişe hissetmekteydi ki muhalefetin yeni bir ulusal banka inşa etme talebini de ekonomik anlamda kontrolün kaybolması olarak yorumlamıștır. Bundan dolayı Van Buren, devlet bankalarından federal hükümet fonlarının ayrı tutulması ve bu paraların görevli denetçiler tarafından sıkı takibe alınmasını ve bunun toplanması için bağımsız bir hazine kurulmasını talebini savunmuştur (Curtis, 2002: 131). Van Buren ayrıca ekonomik krizin çıkma nedenini selefinin yürüttüğü politikalarından ziyade yabancı iş ve finansal kurumların yetersizliğinden olduğunu düşünmüştür. Amerikan halkının içinde bulunduğu bu durum refah seviyesini oldukça azaltırken, yeni başkan olan Van Buren içinde büyük bir sorun olmuştur (Silbey, 2020).

Van Buren'in başlıca başarısı Amerika'da mali / finansal kurumlar reformunu düzenlemesi olmuştur. Ayrıca kriz Van Buren kabinesi tarafından Anglo-Amerikan savaşına dayanan bir dizi olayın neden olduğu küresel ekonomik krizin yansıması olarak okunmuştur. 1837 buhranındaki temel faktör, bankacılar ve ithalatçılardan fabrika sahiplerine ve çiftçilere kadar tüm ekonomik unsurların elinde para ve kredi arzının azalması ve ortadan kalkmasıydı ki bu durum oldukça karışıktı. Van Buren, federal fonları özel şahıslardan ve şirketlerden ayıracak bir yapının kurulmasını önerdi ki böyle bir teklifin devletin devasa boyutunu ve harcamalarını azaltacağ (Rayback, 1983: 133). Van Buren ayrica 1837 ekonomik krizini kendi hükümetinin işlevselliğini kısıtladığını ifade ederek hükümetinin arzu edildiği gibi çalışmasının önündeki en büyük engel olarak göstermiştir. Aynı zamanda bu krizin sadece Amerika ile ilgili bir durum olmadığını Rusya ve Asya'dabirçok ülkenin aynı finansal sorunlardan muzdarip olduğu yönünde propaganda yaparak kendi hükümetine karş1 gelebilecek eleştirilere de cevap niteliğinde beyanatlarda bulunmuştur (Hummel, 2001: 188).

\subsubsection{Gözyaşı Yolu Felaketi}

Güneybatı'da yaşayan yerlilerin büyük bir kısmı Federal hükümetin Oklahama'ya göç etmesini talep etmesine rağmen Kuzeybatı'daki birçok yerli kabile anayurtlarını terk etmemek için Washington'a karşı mücadele etmeye devam etmiştir. On yedi bin Cherokee, dört bin Seminole ve binden fazla kaçak siyahi köle bulundukları yerleri terk etmemek istemesi Amerika Birleşik Devletleri tarihinin önemli soykırımlarla anılmasına neden olmuştur. $\mathrm{Bu}$ süreçte yaşanan birçok çatışma ve katliamlar 'Gözyaşı Yolu' anlamına gelen 'Trails of Tears ' olarak Amerikan siyasi tarihine geçmiştir (Hummel, 2001: 194). 1800'de başlayan Cherokeelerin tehcir politikaları Georgia'da yaşadıkları bölgelerde altın madenlerinin bulunması ile birlikte Amerikan hükümetinin zorunlu tehcir ve sürgün politikalarıyla başlamıştır. 1837 yılında çıkan tehcir yasası ile birlikte Cherokeeler topland 1 ve Tennessee, Ohio, Mississippi ve Arkansas Nehirleri kullanılarak teknelerle kıyıdan daha iç bölgelere gönderildi. Birçoğu kaderlerini beklerken tehcir kamplarında tutuldu. $\mathrm{Bu}$ süreç yerli kabileler tarafindan ağlama yolu veya izi olarak tanımlanarak kültürel bir hafıza olarak zihin dünyalarında kalmıştır (Webest2: 2018). Bu olay Amerika dışında ve içinde birçok tepkiye ve kınamaya neden olmuştur. (Hausman, 2011). 
Florida'da yaşayan Seminole Kızılderilileri ise, yaşadıkları toprakları terk etmek istemiyorlardı. Seminole halk1 5000 Amerikan askeriyle savaşmak zorunda kaldı. 1838'de Seminole halkının güçlü lideri Şef Osceola'nın öldürülmesi de direnişi bastıramadı. Seminole halkı 1840 yılına kadar direnebildi ve binlercesi öldürüldü. Başkan Van Buren bu katliamlardan dolayı Amerikalılar tarafindan çok da eleştirildiği söylenemez (Department of State, 2018).

\subsubsection{Amistad Davas1}

1839 Haziran ayında 52 Afrikalı esir köle taciri İspanyolların kontrolündeki Amistad isimli gemide isyan başlatmış ve mürettebattan sadece iki kişiyi sağ brrakarak gemi mürettebatının hepsini öldürdüler. Gemiyi Afrika'ya götürmesi için esirlerin lideri konumunda olan Joseph Cinque İspanyol kaptana emir verir. Kaptan gündüzleri Afrika'ya doğru giderken geceleri kuzeybatıya gider. Ağustos ayında Long İsland kıyılarında Amerikan askerleri gemiyi alıkoyar. Gemide 4'ü çocuk 36 Afrikalı esir kalmıştır. Connecticut'da esirler isyan, korsanlık ve cinayet ile yargılanır. Mahkeme, esirlerin avukatlarının bulduğu belgeler 1şı̆̆ında köle olmadıklarını ve serbest bırakılmalarına karar verir. Van Buren köleci olan Kuzey oylarını kaybetme endişesi ve esirlerin iadesini isteyen İspanyol İmparatorluğu ile ilişkileri bozmamak gayretiyle davayı temyize, bir üst mahkemeye taşır ve kendi partilerine yakın bir yargıcı davaya tayin eder. $\mathrm{Bu}$ dava kölelik karşıtlarını daha çok agresifleştirmiştir (Yale, 2018).

Van Buren'in Dışişleri Bakanı John Forsyth esirlerin Küba'ya iadesi için çalışsa da başarılı olamaz. Dava Amerikan yüksek mahkemesine taşınır. 74 yaşındaki eski başkan John Quincy Adams esirlerin avukatlığını üstlenir. Mahkeme esirlerin köle doğmadığına ve kaçırılmış hür insanlar olması sebebiyle Sierra Leone'ye hükümet tarafından götürülmesine hükmeder (Yale, 2018).

\section{Martin Van Buren Dönemi Amerikan Dış Politikası}

Pragmatik bir lider olan Andrew Jackson, New York valisi olan Van Buren'in başkanlık seçiminde başarılı çalışmalarından dolayı dış işleri bakanı olarak atamıştır. Bu da Van Buren'in hukuki eğiliminin profesyonel anlamda dış politika konularında da güçlenmesine ve Amerikan siyasetinin en önemli ve mahrem alanı olan dış işleri bakanlığı kurumu hakkında önemli tecrübeler kazanmasını sağlamıştır. Ayrıca şüphesiz ki dış işleri bakanı olduğu zamanki vakur tavrı, soğukkanlılığı ve gün geçtikçe artan siyasi ve finansal iletişimleri onu Amerikan başkanlığına taşıyan en önemli etkenlerden biri olmuştur.

Van Buren, Amerikan başkanlığı seçim sonuçlarının açıklanmasından sonra yapmış olduğu ilk halka sesleniş konuşmasında selefi olan Jackson'un diş politika yaklaşımında herhangi bir değişim olmadığını, bütün devletler ile dostane ilişkileri sürdüreceğini, Amerikan halkının haklarının korunacağı, vatandaşlar arası firsat eşitliği ve adaleti savunacağını ifade etmiştir. Ayrıca İngiltere ile sıkıntılı ilişkilerin devam etmesine rağmen İngiltere ve Amerika'nın dostane ilişkilere sahip olduğunu da ifade etmiştir. Fransa ile olgun ve dostane olan ilişkilerin daha da ileri ve uyumlu bir hale götürüleceği gibi temennilerde bulunarak Amerika'nın denizaşırı devletler ile ilişkilerinden bahsetmiştir (American History, 2018).

Fakat aşağıda örneklerle inceleneceği gibi sınırlı da olsa ulus inşasını tamamlama ve devletin kurumsal yapısını güçlendirmek için bakıldığında savunmacı; kıtada otorite olduğunu ve kendi lehine yapılan saldırgan girişimleri de yumuşak karşılamayacağını fiilen göstermiş ve sert politikalar izlemek durumunda kalmıştır.

\subsection{Caroline Vakası (Caroline Affair)}

Amerika Birleşik Devletleri açısından Meksika başta olmak üzere bir dizi dış güvenlik sorunu varken ülkenin Kuzeyinde çıkan bir isyan Van Buren'i oldukça zor bir duruma sokmuştur. 1837 yılında temelinde Kanada'daki İngiliz yönetimine duyulan memnuniyetsizlik olan bu isyan Amerikan vatandaşı olan William Lyon'un liderliğinde Nieagara Nehrinde bulunan Navy adasında meydana gelmiş ve birçok Kanadalı da müdahil olmuştur. New York güvenlik güçlerinin kendi vatandaşlarını kontrol edememesi nedeniyle İngilizler karakolların silahsızlandırılması kararını vermiştir. İsyancıların bulunduğu Caroline gemisinin batırılmasını emir vermiștir. Gemi uluslararası sınırlara ulaşmadan hukuksuz bir şekilde batırılmıştır (Curtis, 2002: 135) Bu olay aynı zamanda Amerika Birleşik Devletleri ve İngiltere Krallı̆̆ dönem iki devletin gündeminde ciddi bir şekilde yer etmiştir.

Amerika ve Kanada iyi ilişkilere sahip olduğundan 1837'de Kanada'da İngilizlere karşı çıkan ayaklanma Amerikalılar tarafından silah yardımı ile desteklenmiștir. Kanada'da İngiliz taraftarı olan McLeod simli bir kişinin Amerikan sınırını geçerek Amerikan vatandaşı bir kişiyi öldürmesi ilişkileri bozmak ile birlikte sınır sorununu ortaya çıkarmıştır. Bu hadise sonrası idama mahkûm edilen McLeod İngiltere ve Amerika arasında uluslararası bir soruna sebep olmuştur. 1842'de tarafların anlaşması sonrası serbest bırakılan McLeod ikili ilişkilerin de düzelmesine katkı sağlamış ve İngiltere ve Amerika arasında 1842 yılında Webster-Ashburton Anlaşması ile günümüze kadar devam eden Kanada Amerika sınırı çizilmiştir (Armaoğlu, 2014: 696).

\subsection{Aroostook Çatıșması}

1839 yılında Kuzey Maine'nin uzak bir bölgesi olan ormanlık ve kerestelik ağaç bakımından zengin Aroostook bölgesinde yeni bir çatışma baş gösterdi. 1783 yılındaki barış anlaşmasında Maine ve Brunswick sınırını ayıran bölge üzerinde anlaşılamamış yedi milyon hektarlık bir bölge idi. 1830'lu yıllarda Amerikan ve İngiliz vatandaşları bu verimli keresteleri değerlendirme çabalarına girdiler. Kanadalı yetkililer bir Maineli Amerikan vatandaşını tutuklayarak New Brunswick hapishanesine koydular. Teğmen olan New Brunswick valisi Sir John Harvey tutuklama kararını doğru bularak onayladı ve tüm Amerikalıların bölgeden çekilmesini isteyen bir bildiri yayınladı. Maine valisi John Fairfield ise bin kişilik asker ve on bin dolar para için meclisten onay almak istiyordu. Durumdan haberdar olan Başkan Martin Van Buren İngiliz bakan Hanry Fox ile görüşüp anlaşarak tüm tarafların Aroostook'u terk etmeleri için muhtıra çektiler. Fakat Maine valisi Fairfield başkana rest çekerek savaş hazırlıklarına devam edeceğini bildirdi. Böyle durumlara can sıkmayacak kadar profesyonel bir 
siyasetçi olan Başkan Van Buren, General Winfield Scott’u kızgın valiyi ve askeri birlikleri kontrol altına alma göreviyle Augusta'ya gönderdi. Scott henüz yolda iken kongre başkana sınırı savunması için on milyon dolar ve elli binden fazla asker kullanma yetkisi vererek savaşı körüklüyordu. Scott bunlara gerek kalmadan krizi bitirme görevini başarıyla yerine getirdi (Curtis, 2002).

\subsection{Teksas Sorunu}

Van Buren'in Amerika Birleşik Devletleri Başkanlık tarihi açısından incelediğimizde iç politikadan daha ziyade diş politik meselelerde ülkesi için daha önemli gelişmelere imza attığ1 gözlenmektedir. Ekonomik kriz ile meşgul olurken Teksas sorunu gibi Amerika'yı ikiye bölen konuları ustalıkla yöneterek başkanlıktaki ehliyetini ispat etmiştir. Teksaslılar 1837'de Amerika Birleşik Devletleri'ne katılmak için siyasi olarak baskı yapıyorlardı. Teksaslılar, Meksika'yı barbar olarak tanımlayarak Amerikan halkına Teksas'1 kendileri kontrol etmedikleri takdirde bunu başka bir büyük güç kendilerine sorun yaratmak için kullanacağını ikna ederek Amerikan kamuoyunu Teksas'ın Birliğe katılımı için ikna etmeye çalıştılar. Hatta Teksas'ın başka büyük devletlerle Amerika Birleşik Devletleri'ne zararı olabilecek anlaşmalar yapmak zorunda kalacağını savundular (Curtis, 2002: 134).

Van Buren, Teksas'ın köleci yapısından dolayı Kuzey ile Güney arasındaki güç dengesini bozacağını bildiği için ve mevcut ekonomik kriz döneminde Meksika ve onu destekleyeceğini düşündüğü İngiltere, Hollanda, Belçika hatta Fransa ile ilişkileri bozmak ve de silahlı çatışmaya girmek istemiyordu. Bu konuda hiç ayrı düşmediği selefi Andrew Jackson'la farklı düşüncedeydi. Kongrede bağımsız bir devletin ilhakının hukuki olmadığını ve emsalinin bulunmadığını belirtti. Eski başkan John Quincy Adams'da ilhakın Meksika'ya savaş ilanı olacağı ve Kuzey Güney dengelerini bozacağı görüşünü dile getirerek Van Buren'i desteklemiştir (U.S. Department of State Archive, 2009).

1836 yılından 1844 yılına kadar Teksas bağımsız bir devlet olarak devam etti. Ayrica Fransa, İngiltere, Hollanda ve Belçika'nın Teksas'ın bağımsızlığını tanıdı ve güçlü kalabilmesi için destekledi. İngiltere'nin cömert ekonomik ve askeri yardımları ile daha önce Kanada'dan hissettiği tehdit ve endişeyi bu sefer güney sınırlarından hissetmeye başladı. Eski Başkanlardan Andrew Jackson'un Başkan Tyler'i Teksas'ın ilhakı konusunda sürekli cesaretlendirmesi neticesinde 12 Nisan1 844 tarihinde Teksas Amerika Birleşik Devletlerine katılmıştır Bu durum Teksas'ın hamisi olan İngiltere ve Fransa tarafindan istemeyerekte olsa kabul edilirken Meksika ise Amerika ile diplomatik ilişkilerini kesme kararı almıştır (Armaoğlu, 2014: 694). Van Buren, ayrıca başkanlığı sırasında Teksas meselesine oldukça ihtiyatlı yaklaşmış, Teksas'ın bir taraftan bağımsızlığını tanıyarak diğer taraftan ilişki ve entegrasyonunu dolaylı olarak güçlendirerek başka bir taraftan ise Meksika ile çatışmadan Teksas'ın Biriğe katılımına giden süreci başarılı bir şekilde yönetmiştir.

Van Buren, kurumsal temelleri ve devlet mekanizması tam anlamı ile oturmamış bir Amerika'yı yaşadığı yıllarda özellikle Avrupa'da meydana gelen birçok ekonomik, güvenlik, siyasi ve toplumsal sorunlara bulaştırmaması ve Amerika'nın gücünü önemli derecede azaltacak savaşlara müdahil etmemesi (Fransa ve İngiltere ile doğrudan savaş çıkarmaması gibi) Van Buren'in dış politika açısından Amerika'nın konjonktürel çıkarları açısından çok önemli bir başkan olduğunu göstermektedir (Hummel, 2001: 257).

\section{Sonuç}

Van Buren, Amerikan siyasi tarihi açısından önemli olmak ile diğer kurucu başkanlara kıyas edildiğinde daha az popüler olduğu bilinmektedir. Bunun ile birlikte, Amerikan ulusunun çıkarı açısından önemli gelişmelere imza attığı konusu çalışmada değinilmiştir. Ayrıca, ilk Amerikan başkanları ve özellikle Van Buren hakkında yeterli akademik çalışmalar hem dilimizde hem de İngilizce de bulunmaması, bulunan kaynaklarında Van Buren'in kişisel yaşamı ile ilgili olması iç ve diş politikalara yoğun bir şekilde temas etmemesi çalışmamızın tamamlanması açısından zor kısımları oluşturmuştur.

Bu çalışmada Amerika'nın sekizinci başkanı olan Martin Van Buren'in Amerikan politikasındaki yeri, konjonktürel anlamda Amerika'nın iç ve dış politikalarına ne gibi katkılar sunduğu analiz edilmiştir. Ayrıca Van Buren'in siyasi hayatının önemli kareleri hakkında vurgular yapılarak Van Buren'in politik düşüncesinin arkasındaki temel motivasyonlar anlaşılmaya çalışmıştır. Van Buren'in siyasi hayatı iz bırakan başarılarla geçmiştir. Karşı karşıya kaldığı politik sorunlara daima dâhiyane çözümler önermiştir. Ülkesini 1837 ekonomik krizi anlarında ayakta tutabilmeyi başarmış, toplumsal bölünmelerde Güney ve Kuzey’i bir arada tutabilmiş, birçok sınır anlaşmazlıklarında ülkesini savaşa sokmamayı başarabilmiştir. Başkanlığı boyunca Teksas meselesi gibi özel durumlarda selefinin politikalarının doğurduğu olumsuz neticelerle mücadele ederek adeta Andrew Jackson'un ardını temizlemek durumunda kalmıştır. Jackson'un çok parlak ve hareketli geçen iki dönem başkanlığı Van Buren'in başarısını ve dâhiyane siyasi kimliğini gölgelemiştir.

Çalışma, ilk dönem Amerika Birleşik Devletleri siyasi tarihi ve Başkan Van Buren'in siyasi hayatı ve politikalarının anlaşılmasına yönelik önemli bir kaynak olma özelliği taşırken aynı zamanda da Amerika Birleşik Devletleri'nin inşa sürecinde yaşanılan ekonomik, siyasi, sosyal ve hukuksal problemlerinde anlaşılması açısından önemli bir kaynak olma amacı taşımaktadır. Bununla birlikte, Amerikan dış politikasında Monreo Doktrini etkisinin hissedilmesi açısından Van Buren dönemi de ayrıca önem arz etmektedir. Mümkün oldukça kıta ötesi problemlerden kendini soyutlayan Amerika, kalıcı sınırlara erişmek, tartışmalı alanlardan uzak durmak, iç politikada ekonomik kriz ile mücadele etmek ve yerli meselesi ile ilgilenmek Van Buren döneminde asıl önemli ve belirleyici siyasi öncelikler olduğu çalışmada gösterilmiştir.

\section{Kaynakça}

American History. (2018). State of the Union 1837. (Erişim: 18.11.2018)

http://www.let.rug.nl/usa/presidents/martin-vanburen/state-of-the-union-1837.php

Armaoğlu, F. (2014). 19. Yüzyll Siyasi Tarihi 1789-1914 (14 b.). İstanbul: Timaş Yayınları. 
Armstrong Economics (2018). The Great Financial Panics in History-Panic of 1837. (Erişim: 16.11. 2018) armstrongeconomics.com:

https://www.armstrongeconomics.com/panic-of$1837 /$

Cole, D. B. (1984). Martin Van Buren and the American Politics Syste. Princeton, New Jersey: Princeton University Press.

Curtis, J. C. (2002). "Martin Van Buren”, içinde : H. F. Graft (Ed.), The Presidents A Referance History. New York: The Gale Group.

Department of State (2018). Biographies of the Secretaries of State : Martin Van Buren (1782-1862), (Erişim: 10.09.2018),

https://history.state.gov/departmenthistory/people/va n-buren-martin

Hausman, B. M. (2011). Riding the Trail of Tears. Nebraska: University of Nebraska Press.

Healy, G. P. (1964). “Martin Van Buren”. F. Frediel (Ed.) içinde, Presidents of The United States of America. Washington D.C.: White House Historical Association.

History (2009). Martin Van Buren. (Erişim: 13.10.2020), https://www.history.com/topics/uspresidents/martin-van-buren

Hummel, J. R. (1999). "Martin Van Buren: The Greatest American President". The Independent Review. Vol:4: 255-281

Hummel, J. R. (2001). Martin Van Buren: The American Gladstone (Erişim: 22.06.2018), https://mises.org/library/martin-van-buren-americangladstone

Jarvis, J. W. (1964). The Presidents of the United States of America. Washington D.C.: White House Historical Association.

Koç, E. (2017). “ABD Dış Politika Doktrinlerinin Ortadoğu'ya Yansıması”. R. Pehlivan, \& S. Demirkılınç (Ed.), 2. Uluslararası Çin'den Adriyatik'e Sosyal Bilimler Kongresi içinde Hatay: İktisat yayınları.

Library of Congress. (2011). The Red Fox of Kinderhook. (Erişim: 28.11.2018) www.loc.gov/wiseguide/dec11/fox.html

Mintz, M. M. (1949). The Political Ideas Of Martin Van Buren. New York: New York History.

Mintz, S., \& Davis, B. B. (tarih yok). Amistad Affair, (Erişim: $\quad 11.10 .2018$ ) glc.yale.edu: glc.yale.edu/document-essay-amistad-affair
Nevis, A., \& Commager, H. S. (2014). ABD Tarihi. (H. İnalcık, Çev.) Ankara: Doğu Batı.

Özdal, B., \& Karaca, R. (2015). Diplomasi Tarihi I "Modern Diplomasinin Gelişiminde Etkili Olan Unsurlar. Bursa: Dora yayınlar1.

Rayback, J. G. (1983). "Martin Van Buren: His Place in the History of New York and the United States". New York History, 64(2).

Richards, L. L., Miller, M. R., \& Gilg, e. (2006). Martin Van Buren's Life at Lindenwald, 1839-1862. Massachusetts, Amherst: National Park Service U. S. Department of the Interior.

Sander, O. (2009). İlk Çăglardan 1918'e (18 b.). İstanbul: İmge Yayınevi.

Silbey, J. (2020). Martin Van Buren: Life Before The Presidency. (Erişim: 10.09.2020), millercenter.org: http://millercenter.org/president/vanburen/lifebefore-the-presidency

Silbey, J. (tarih yok). Martin Van Burden: Domestic Affairs. 11 14, 2018 tarihinde UVA Miller Cente: https://millercenter.org/president/vanburen/domestic -affairs adresinden alınd

Tocqueville, A. d. (1962). Amerikan Demokrasisi. İstanbul: Türk Siyasi İlimler Derneği Yayınları.

U.S. Department of State Archive (2009). The Annexation of Texas, the Mexican-American War, and the Treaty of Guadalupe-Hidalgo,1845-1848,(Erişim:20.05.2018) https://2001-

2009.state.gov/r/pa/ho/time/dwe/16336.htm

US Senate (2018). VP_ Martin Van Buren. (Erişim: 14.11. 2018),

www.senate.gov/artandhistory/history/common/gene ric/VP_Martin_VanBuren.htm

Webtest2 (2018). Trail of Tears: A Brief History of the Trail of Tears. (Erişim: 20.11.2018), http://webtest2.cherokee.org/About-TheNation/History/Trail-of-Tears/A-Brief-History-ofthe-Trail-of-Tears

Welcbacher, A. (2001). Martin Van Buren. Minnesota: ABDO Publishing Company.

Yale, (2018). Amistad Affair. (Erişim: 11.03.2018), www.glc.yale.edu/document-essay-amistad-affair

270towin (2018). 1836 Presedential Election (Erişim: 10.04.2018), https://www. 


\section{Extended Abstract}

In this study, examined the role of Martin Van Buren, eighth president of US, in American political life and it's analysed his domestic and foreign affairs contributions of his country. We tried to indicate that some highlights about his important frames of political life and thought to be understood his political thought. Martin Van Buren is the first president, who was born in the independent US and also first nonBritish origin among the other presidents at his time. Van Buren, became a lawyer and his interest in politics began very early age from age 18 , if not before. The political life of Van Buren, which started as a delegate in the provincial congress in 1800, was ended Free Soil in 1848.

He started to politics in New York in from Federalist Party then he continued to political life with other parties like: Republicans and Democrats. He elected to the US Senate between 1821-1828, then he became the governor of New York in 1829. On the other side, he appointed the minister of foreign affairs between 1829-1831 and worked as vide president between 1833-1837 in US. He struggled against to slave trade in US, and this also helped him to ascended power in his country. The President Martin Van Buren took office on March 4, 1987, and his mission completed on March 1841 in the US politics via a member of Democratic Party. According to Van Buren, political parties are essential values and useful social tools for country's fate and he supported two party election. During his presidency, some important developments came forward in US politics such as; 1937 Economic Crisis and 1838 Path of Tears which was caused many people's life. Especially, 1937 Economic Crisis was prior concern of Van Buren, because British Financial institutions cut off ensuring money for American banks.

As understood Van Buren, contributed his country power and influence on foreign affairs rather than domestic affairs in his country. When he was dealing with economical problems, he also focused on critical problems like, Texas issue. When Texas gained de facto independence from Mexico, thanks to him and his successor Andrew Jackson's strategies annexed by US with peacefully. On the other hand, he managed Amistad Trail in 1839 which was very important consequences in the US political history into next years. When he come to power, putted attention to improve relations with France and UK, but Caroline Affair damaged the bilateral relations with UK. According to some sources Americans supported Canadian revolts against to UK and London blamed to US Government to ensure money and arms them. They solved the problems with sign WebsterAshburton Border Treaty in 1842. Solution of Caroline Affair in favor of Van Buren but its show that small border problems between parties drag both sides to conflicts. He well known in US politics as "Sly fox" and "little magician" because of his shifting critical maneuver on the domestic and foreign affairs. Without doubt Van Buren is very important figure among the other US presidents but not consider much important both in US and abroad. 